\title{
Privileges Against Self-Incrimination in California
}

\author{
Allen H. Barr*
}

THE introduction of the doctrine against self-incrimination into the California Constitution was uneventful. ${ }^{1}$ A part of the prosaic ${ }^{2}$ declaration of rights which was recommended by the Select Committee of the 1849 constitutional convention, ${ }^{3}$ this doctrine encountered no objections to its acceptance ${ }^{4}$ and ultimately einerged as section 8 of article I:

"No person shall ... be compelled, in any criminal case, to be a witness against himself ...."

The history of this clause in the 1879 convention was equally commonplace. The clause was renumbered as article I, section 13 by the Committee on Preamble and Bill of Rights, which commented that the clause was based on both the 1849 constitution and the sixth aniendment of the Federal Constitution. ${ }^{5}$ The Committee on Revision made no changes in the clause. ${ }^{6}$

Even as late as 1930 no innovations in defining these privileges were considered, for the existing phraseology was tacitly approved in the report of California constitutional commission to the governor, ${ }^{7}$ although a model constitution prepared by the Committee on State Government of the National Municipal League and published under the same cover deleted all provisions for the privileges against selfincrimination. 8

*Executive Secretary of the Institute of International Relations, Mills College; A.B., LC.B., University of California. Author of articles in various legal periodicals.

\footnotetext{
1 Hunt, The Genesis of California's First Constirution (1895) 42.

2 It was extracted from the New York Bill of Rights. Browne, REPORT of THE Debates in the Convention of California (1849) 31.

${ }^{3}$ Ibid. at 30 . The majority report of this committee was delivered September 7, 1849, by Chairman Myron Norton.

4 Ibid. at 41.

5 1 Willis and Stockton, Debates and Procefoings of the Constitutional Convention of the State of CaItForata (1880) 179.

${ }^{8} 3$ ibid. at 1491.

7 Report of California Constitutional Comantsion to Governor of Caiffornia (1930) art. I, \$13.

8 Ibid.
} 


\section{LEGISLATIVE INTERPRETATION AND AMENDMENT}

In 1872 the legislature gave initial effect to the constitutional provision. Section 688 of the Penal Code reiterated that no person was to be compelled in a crininal action to be a witness against himself. ${ }^{9}$ In Penal Code Section 1323, as adopted in 1874, a person charged with the commission of an offense was stated to be a competent witness at his own request, but the code cautioned that this authorization should not be construed as "compelling any such person to testify". This section was more adequately phrased by a revision two years later. ${ }^{10}$

The Code of Civil Procedure still contains the original legislative interpretation of these privileges. Section 2065 requires a witness to answer pertinent questions even though his answers establish a claim against him, but provides that he does not have to give any answer which would have tendency to subject him to punishment for a felony nor tend to degrade his character. However, another section allows impeachment of a witness by showing that he has been convicted of a felony. ${ }^{11}$ Even the witness himself must answer as to the fact of his previous conviction. ${ }^{12}$

The most important change in the privileges was the creation of the right to comment on a defendant's exercise of his privilege. California law, like the common law, had conceded that the accused might refuse to testify without creating any unfavorable inferences. ${ }^{13}$ Thus it was error if the prosecuting attorney insinuated that guilt might be inferred fron such refusal, ${ }^{14}$ or if comments by the court contained similar implications. ${ }^{15}$ The strictness of these rules, the

9 Based on California Criminal Practice Act, Cal. Stats. 1851, p. 213, §13, and on N. Y. Cran. Proc. Code (1850) 10.

10 atgendmonts to the Codes of Calmifornia (1874) 451.

11 CaL. Code Crv. Proc. \$2051.

12 Ibid. \$2065.

13 People v. Glass (1910) 158 Cal. 650, 112 Pac. 281; People v. Black (1925) 73 Cal. App. 13, 238 Pac. 374; People v. Calvert (1926) 80 Cal. App. 50, 251 Pac. 244; People v. Bender (1933) 132 Cal. App. 753, 23 P. (2d) 439.

14 People v. Tyler (1869) 36 Cal. 522; People v. Brown (1878) 53 Cal. 66; People v. Mirandi (1918) 38 Cal. App. 178, 175 Pac. 653; People v. Amer (1908) 8 Cal. App. 137, 96 Pac. 401. However, in People v. Mayen (1922) 188 Cal. 237, 205 Pac. 435, where the accused took the stand, the prosecution attorney was allowed to conment as to what was pertinent but left unsaid. Such insinuations do not always cause a miscarriage of justice. People v. Scott (1924) 66 Cal. App. 200, 225 Pac. 767; People v. Cassidy (1927) 86 Cal. App. 45, 260 Pac. 313.

15 Notes (1934) 22 Calif. L. Rev. 564; (1936) 25 Calif. L. REv. 212. 
pressure of opponents of the privileges against self-incrimination, and the practical advantages to be gained from allowing the court to comment upon the evidence combined to lead to the first amendment to the constitutional statement of the privileges. Proposed as a Senate constitutional amendment in $1933,{ }^{16}$ and adopted as law on November 1, 1934, the amended section 13 of article $I$ was henceforth to read,

“... No person shall be ... compelled, in any criminal case, to be a witness against himself, but in any criminal case, whether the defendant testifies or not, his failure to explain or to deny by his testimony any evidence of facts in the case against him may be commented upon by the court and by counsel and may be considered by the court or the jury."

This amendment was immediately put into effect by the legislature, by adding identical words to appropriate code sections. ${ }^{17}$

No limitations of the powers given in this amendment have as yet been declared, for subsequent decisions not only allow the prosecuting attorney to make reasonable comments ${ }^{18}$ and deprive the defendant of his former right to a jury instruction explaining his privilege, ${ }^{19}$ but they even allow the prosecutor to state his personal conviction of the guilt of the accused. ${ }^{20}$ However, it is reasonable to conjecture that one limitation already applied to another constitutional privilege of commenting ${ }^{21}$ will also apply to article I, section 13: the court may not make an argument to the jury under the guise of a "comment". ${ }^{22}$ The same limitation should apply to comments by counsel. Although the amendment expressly covers only criminal cases,

16 Cal. Sen. Const. Amend. (1933) No. 23, sponsored by Jones.

17 See CaL. PEN. Code $\$ \$ 1093,1323$ and 1439.

18 People v. Pratt (1938) 26 Cal. App. (2d) 618, 80 P. (2d) 87; People v. Swenson (1938) 28 Cal. App. (2d) 636, 83 P. (2d) 70.

19 People v. Dozier (1939) 35 Cal. App. (2d) 49, 94 P. (2d) 598. Formerly it was error for the court to refuse an instruction explaining defendant's right to remain mute. People v. Tyler, supra note 14. But it was not error for the court to neglect to give such an instruction where the defendant failed to request it. People v. Flynn (1887) $73 \mathrm{Cal}$. 511, 15 Pac. 102.

20 People v. Zirbes (1936) 6 Cal. (2d) 425, 57 P. (2d) 1119; People v. Perry (1939) 14 Cal. (2d) 387, 94 P. (2d) 559; People v. Owens (1936) 11 Cal. App. (2d) 724, 54 P. (2d) 728.

21 Art. VI, §19, which reads, "Judges shall not charge juries with respect to matters of fact, but may state the testimony and declare the law."

22 People v. Talkington (1935) 8 Cal. App. (2d) 75, 47 P. (2d) 368. 
it is clear that guilt may be inferred in civil cases from the refusal of $a$ witness to answer questions on the grounds of self-incrimination. ${ }^{23}$

\section{JUDICIAL INTERPRETATION}

The customary supposition that there is but one privilege against self-incrimination seems inaccurate, for analysis discloses two privileges. The first may be invoked by a defendant only in a criminal case; the second by any witness in almost any case.

\section{Privilege of the Accused to Refuse to be Sworn as a Witness}

The frst privilege is that of the defendant in a criminal casewho may refuse even to be sworn as a witness. ${ }^{24}$ This right which may be claimed only by the defendant ${ }^{25}$ protects him against documentary ${ }^{26}$ and testimonial incriminations, but does not completely safeguard disclosure of physical circumstances. ${ }^{2 \pi}$ For example, the accused can be made to arise for identification in court, ${ }^{28}$ his fingerprints can be taken and introduced in evidence for comparison with prints left at the scene of the crime, ${ }^{29}$ or he may even be required to visit the scene. ${ }^{30}$ This privilege exists only in a "criminal case". As defined, this phrase appears broader in scope than a criminal prosecution, for the accused may claim his privilege in a juvenile court proceeding, ${ }^{31}$ a trial on the issue of insanity, ${ }^{32}$ or a proceeding to remove a sheriff from office under code provisions. ${ }^{33}$ On the other hand,

23 Fross v. Wotton (1935) 3 Cal. (2d) 384, 44 P. (2d) 350.

24 People v. Calvert, supra note 13; People v. McGowan (1926) 80 Cal. App. 293, 251 Pac. 643.

25 That persons who are not accused cannot refuse to be sworn, see text infra.

28 The accused may not be asked to produce incriminating documents. People v. Webber (1919) 44 Cal. App. 120, 186 Pac. 406; People v. Chapman (1921) 55 Cal. App. 192, $203 \mathrm{Pac}$. 126. However, in neither case was the erroneous request held prejudicial. 27 Query: Must an accused subunit to examination by medical experts? $C f$. People v. Bundy (1914) 168 Cal. 777, 145 Pac. 537; People v. French (1939) 12 Cal. (2d) 720, 87 P. (2d) 1014; People v. Strong (1931) 114 Cal. App. 522, 300 Pac. 84.

23 People v. Goldenson (1888) 76 Cal. 328, 19 Pac. 161; People v. Oliveria (1899) 127 Cal. 376, 59 Pac. 772 ; People v. Ferns (1915) 27 Cal. App. 285, 149 Pac. 802. Evidence is admissible that the defendants' demeanor within the courtroom differs from that observed outside. People v. Cornell (1928) 203 Cal. 144, 263 Pac. 216.

29 People v. Jones (1931) 112 Cal. App. 68, 296 Pac. 317; People v. Ramirez (1931)

113 Cal. App. 204, 298 Pac. 80; see also Kidd, The Right to Take Fingerprints, Mcasurements and Photographs (1919) 8 CaLIF. L. REv. 25, 26; and Cal. Stats. 1917, p. 1391.

30 People v. Adams (1926) 198 Cal. 454, 245 Pac. 821.

31 In re Tahbel (1920) 46 Cal. App. 755, 189 Pac. 804.

82 People v. Lamey (1930) 103 Cal. App. 66, 283 Pac. 848.

83 Thurston v. Clark (1895) 107 Cal. 285, 40 Pac. 435. 
he may not refuse to be sworn in a disbarment proceeding, ${ }^{34}$ a bankruptcy hearing, ${ }^{35}$ a statutory proceeding for the recovery of property embezzled from the estate of a decedent, ${ }^{36}$ an action by the attorney general to establish an escheat of land conveyed contrary to the alien land laws, ${ }^{37}$ or in a grand jury investigation where the proposed witness is not already in custody.$^{38}$ Analogously, motorists are bound by the "hit and run" statute to stop and give information about themselves. $^{39}$

But even a recalcitrant defendant may still suffer the ignominy of hearing his prior statements repeated to the jury. Testimony previously given under oath in an earlier proceeding is admissible if voluntarily given on a former trial of the defendant on the same charge, ${ }^{40}$ during the criminal prosecution of another, ${ }^{41}$ during a civil case, ${ }^{42}$ during a coroner's inquest ${ }^{43}$ or even before the grand jury. ${ }^{44}$

Admissions against defendant's own interest are admissible even though made out of court ${ }^{45}$ and not voluntarily spoken. ${ }^{46}$ However, if the statement is so complete as to acknowledge guilt of all the ma-

34 In re Vaughan (1922) 189 Cal. 491, 209 Pac. 353, (1923) 11 CaLIF. L. REv. 137: McIntosh v. State Bar (1930) 211 Cal. 261, 294 Pac. 1067; Kidd, Some Recent Cases in Evidence (1925) 13 CaIIF. L. REv. 285.

35 Note (1925) 13 CaxIF. L. Rev. 259. Cf. Ex parte Clarke (1894) 103 Cal. 352, 37 Pac. 230.

36 Levy v. Superior Court (1895) 105 Cal. 600, 38 Pac. 965.

37 People v. Nakamura (1932) 125 Cal. App. 268, 13 P. (2d) 805, no criminal intent.

38 In re Hoertkorn (1936) 15 Cal. App. (2d) 93, 59 P. (2d) 218; In re Lemon (1936) 15 Cal. App. (2d) 82, 59 P. (2d) 213, (1937) 10 So. CarIF. L. Rev. 211. But if he is in custody at the time and it is not wamed of his privilege, the testimony is inadmissible in the subsequent trial. People v. O'Bryan (1913) 165 Cal. 55, 130 Pac. 1042.

30 CAx. VEr. CODE $\$ 482$. This section does not violate the privilege against selfincrimination. People v. Diller (1914) 24 Cal. App. 799, 142 Pac. 797; People v. Fodera (1917) 33 Cal. App. 8, 164 Pac. 22.

40 See People v. Duniop (1915) 27 Cal. App. 460, 150 Pac. 389; People v. Boyd (1924) 67 Cal. App. 292, 227 Pac. 783.

41. People v. Barrios (1921) 52 Cal. App. 528, 199 Pac. 58. See People v. Mitchell (1892) 94 Cal. 550, 29 Pac. 1106.

42 People v. Wieger (1893) 100 Cal. 352, 34 Pac. 826.

ss See People v. Taylor (1881) 59 Cal. 640, 650; People v. Perry (1939) 14 Cal. (2d) 387,94 P. (2d) 559.

14 See People v. Sexton (1901) 132 Cal. 37, 64 Pac. 107, as explained in People v. O'Bryan, supra note 38, at 62, 130 Pac. at 1045 (cf. note 38, supra, and text thereto); People v. Byers (1936) 5 Cal. (2d) 676, 55 P. (2d) 1177.

45 People v. Miller (1898) 122 Cal. 84, 54 Pac. 523; People v. Knowiton (1898) 122 Cal. 357, 55 Pac. 141; People v. Willard (1907) 150 Cal. 543, 89 Pac. 124; People v. Panagoit (1914) 25 Cal. App. 158, 143 Pac. 70.

16 People v. LeRoy (1884) 65 Cal. 613, 4 Pac. 649; People v. Dye (1915) 29 Cal. App. 169, 154 Pac. 875; People v. Camperlingo (1924) 69 Cal. App. 466, 231 Pac. 601. 
terial elements of the crime, it becomes a confession, and is admissible only if voluntarily made. ${ }^{47}$

Waiver of this first privilege occurs when the defendant takes the stand in his own defense. ${ }^{48}$ Such waivers are not without limitations, for although the defendant as a witness is subject to cross-examination and impeachment in the usual manner, ${ }^{40}$ and under the code requirement a witness must answer whether he has been previously convicted of any felonies, ${ }^{50}$ still he may not be cross-examined on matters to which he has not testified ${ }^{51}$ nor be called thereafter as witness for the prosecution. ${ }^{52}$

\section{Right of a Witness in any Proceeding to Refuse to Answer Certain Questions}

If the person who is called as a witness is not the defendant in a criminal case, he cannot refuse to be sworn. ${ }^{53}$ But once sworn he acquires the other privileges against self-incrimination which may be applied in all proceedings including civil cases, ${ }^{54}$ disbarment proceedings ${ }^{55}$ and investigations before grand juries. ${ }^{50}$ It is not applicable to a private examination arising out of a contractual relationship. ${ }^{57}$ Clearly, the gist of this privilege is not the type of proceeding but rather the type of answer involved. It exists only where the answer will possibly tend to disclose the commission of a felony for

47 People v. Barric (1874) 49 Cal. 342 ; People v. Thompson (1890) 84 Cal. 598, 24 Pac. 784 ; People v. Gonzales (1902) 136 Cal. 666, 69 Pac. 487; People v. Ford (1914) 25 Cal. App. 388, 143 Pac. 1075 ; People v. Clark (1921) 55 Cal. App. 42, 203 Pac. 781.

48 People v. Rozelle (1888) 78 Cal. 84, 20 Pac. 36; People v. Porter (1932) 123 Cal. App. 618, 11 P. (2d) 894; People v. Rose (1935) 9. Cal. App. (2d) 171, 49 P. (2d) 334. 49 People v. Gallagher (1893) 100 Cal. 466, 35 Pac. 80; People v. Brown (1923) 62 Cal. App. 96, 216 Pac. 411; People v. Porter, supra note 48.

50 CAI. Code CIV. Proc. \$2065. This provision does not compel self-incrimination. People v. Romer (1933) 218 Cal. 449, 23 P. (2d) 749; People v. Rose, supra note 48. The provisions of section 1025 of the Penal Code that if defendant has been previously convicted, his admission thereof shall not be alluded to at the trial, are waived when defendant testifies. People v. Ohver (1908) 7 Cal. App. 601, 95 Pac. 172.

51 People v. O'Brien (1885) 66 Cal. 602, 6 Pac. 695; People v. Rozelle, supra note 48; People v. Arrighini (1898) 122 Cal. 121, 54 Pac. 591; People v. Reese (1934) $136 \mathrm{Cal}$. App. 657,29 P. (2d) 450.

52 People v. McGungill (1871) 41 Cal. 429.

63 Ex parte Stice (1886) 70 Cal. 51, 11 Pac. 459.

54 In re Berman (1930) 105 Cal. App. 37, 287 Pac. 126.

65 In re Vaughan, supra note 34.

56 Rogers v. Superior Court (1904) 145 Cal. 88, 78 Pac. 344; In re Lemon, supra note 38, (1937) 10 So. Carif. L. REv. 211.

57 Hickman v. London Assurance Corp. (1920) 184 Cal. 524, 195 Pac 45. 
which the witness may be punished or disclose circumstances having a direct tendency to degrade the character of the witness. ${ }^{58}$

It is insufficient that a possible answer tends to disclose a violation of solne state law; it must be a punishable violation. ${ }^{59}$ Thus, if no offense was committed, if the acts do not constitute a punishable crime, if the criminal statute has been repealed, if the witness has already been once in jeopardy or if the punishment is barred by the statute of limitations, the witness can not claim his privilege. ${ }^{60}$ The so-called immunity statutes, ${ }^{61}$ which usually extend to the witness a complete immunity from punishment for such crimes as may be disclosed, have been held to terminate the privilege against self-incrimination. ${ }^{62}$ However, these statutory provisions have been construed to give subsequent immunity only if the witness is compelled to testify. ${ }^{63}$

The witness is not the ultimate judge of his right to exercise his

68 Cax. Code Crv. Proc. \$2065, provides in effect that a witness need not give an answer which will have a direct tendency to degrade his character unless it be to the very fact in issue, or to a fact from which the fact in issue would be presumed.

The last qualification was given effect in Fross v. Wotton (1935) 3 Cal. (2d) 384, 44 P. (2d) 350 , (1935) 9 So. CALIF. L. REv. 410, where it was held that an inference of fraud, the fact in issue, could be drawn from defendants' witnesses' refusal to answer in a civil suit.

59 Ex parte Cohen (1894) 104 Cal. 524, 38 Pac. 364; Bradley v. Clark (1901) 133 Cal. 196, 65 Pac. 395; In re Crow (1932) 126 Cal. App. 617, 14 P. (2d) 918.

${ }^{60}$ Ex parte Cohen, supra note 59; Rebstock v. Superior Court (1905) 146 Cal. 308, 80 Pac. 65.

61 For California, see CAL. PEN. CoDE, $\$ 64$ (election crimes); $\$ 69$ (lobbying); \$232 (dueling); $\$ 334$ (gambling); §414a (prize fight); CAL. GeN. Laws (1937) act 3814(23) (witness before California Corporation Commissioner); act 1404, $\$ 48$ (witness before Civil Service Commission); act 6386(55) (witness before Public Utility Commission); Cal. Stats 1907, p. 671 (election frauds) ; Cal. Stats. 1915, p. 1272 (insurance misrepresentations); Cal. Stats. 1917, p. 673 (hearing under securities act).

62 Counselman v. Hitchcock (1891) 142 U. S. 547; Ex parte Clarke, supra note 35; Ex parte Cohen, supra note 59 ; People v. Knowles (1915) 27 Cal. App. 498, 155 Pac. 137; People v. Richman (1915) 28 Cal. App. 761, 155 Pac. 142.

63 People v. Eiseman (1926) 78 Cal. App. 223, 248 Pac. 716. In re Connolly (1936) 16 Cal. App. (2d) 709, 61 P. (2d) 490, (1937) 25 Carrf. L. Rev. 622, (1937) 10 So. CALIF. L. REv. 344. Query as to the degree of compulsion necessary: In the Connolly case the defendant was subpoenaed to testify before the legislative committee, examined under oath, and ultimately volunteered infornation for which he was later indicted. Held, such statements were not made under compulsion, and witness was not entitled to immunity otherwise given by Political Code, section 304. But see People v. Schwarz (1926) 78 Cal. App. 561, 248 Pac. 990, which suggests tnat where the witness has been subpoenaed and placed upon oath, there is sufficient compulsion to permit immunity. It has been suggested that possibly the Comolly case limits the Schwarz case "... to the situation in which the incriminating testimony is given in response to specific questions." (1937) 25 CaLIF. L. Rev. 622, 624. 
privilege for it is the court which is to determine whether one of the possible answers might incriminate. ${ }^{\text {ft }}$ If not, the witness must answer. The witness's motive for claiming the privilege, formerly thought to be immaterial, ${ }^{\theta 5}$ now seems to be considered by the court. ${ }^{86}$

Since this privilege is personal a waiver by an unaccused witness is permissible even despite objections of the defendant. ${ }^{67}$ Failure of the witness to claim his privilege at the time the question is asked constitutes a waiver..$^{68}$ However, there is no waiver by having volunteered testimony at a previous jury investigation, ${ }^{60}$ at a preliminary examination ${ }^{70}$ or an earlier deposition of the same case. ${ }^{71}$ The effect of this waiver, like a waiver of the defendant's privilege, ${ }^{72}$ is to require the witness to disclose upon cross-examination all matters about which he was examined in chief. ${ }^{73}$

\section{CONCLUSIONS}

It has been supposed that all the privileges against self-incrimination stem from the constitution. ${ }^{74}$ But the provision we find there does not broadly extend its privileges to all persons; it is explicit that the only persons entitled to the exemptions are those who are requested to testify in a "criminal case". The inference seems clear

64 Ex parte Stice, supra note 53; In re Rogers (1900) 129 Cal. 468, 62 Pac. 47; Nicholson v. Randall Banking Co. (1900) 130 Cal. 533, 62 Pac. 930; Overend v. Superior Court (1900) 131 Cal. 280, 63 Pac. 372; Bradley v. Clark, supra note 59; Rogers v. Superior Court, supra note 56 ; In re Berman, supra note 54.

65 Ibid.; In re Sales (1933) 134 Cal. App. 54, 24 P. (2d) 916.

68 In re Critchlow (1938) 11 Cal. (2d) 751, 759, 81 P. (2d) 966, 970. The court said, "A witness may not invoke the privilege for the purpose of shielding some third person from prosecution."

67 People v. Gonzales (1922) 56 Cal. App. 330, 204 Pac. 1088; People v. Leavitt (1932) 127 Cal. App. 394, 15 P. (2d) 894; People v. Judson (1933) 128 Cal. App. 768, 18 P. (2d) 379.

68 Ex parte Rowe (1857) 7 Cal. 184; Ex parte Stice, supra note 53; People v. Wicger, supra note 42; Bradley v. Clark, supra note 59; People v. Thourwald (1920) $46 \mathrm{Cal}$. App. 261, 189 Pac. 123.

69 Ir re Sales, supra note 65, (1934) 8 So. CaLTF. L. Rev. 51.

70 Overend v. Superior Court, supra note 64 . But the prosecution may introduce in evidence at the trial the testimony given at the hearing.

$\pi$ Cf. In re Berman, supra note 54 , no waiver of right in the second deposition to refuse to answer questions as to the truth of the statements in the first deposition.

72 CaI. PEN. Code $\$ 1323$.

73 People v. Freshour (1880) 55 Cal. 375.

7427 Car. JUR. 23 et seq.

75 The "person" mentioned in the constitution can be either an ordinary witness or the accused. 70 C. J. 722. 
that where the proceeding is not criminal in nature, the privilege of the witness against self-incrimination is not based on article $I$, section 13. It is an interesting and open question whether the California legislature by repealing the privileges given to civil witnesses under Section 2065 of the Code of Civil Procedure could entirely deprive them of their historic privilege against self-incrimination. ${ }^{76}$

76 The witness could not argue that the federal due process of law clause requires exemption from self-incrimination. Twining v. New Jersey (1908) 211 U. S. 78. However, the state clause may prevent abolition of the privilege. Iowa v. Height (1902) 117 Iowa 650,91 N. W. 935. 